Gut, 1968, 9, 561-563

\title{
Effect of sodium desoxycholate on the intestinal absorption and lymphatic transport of oleic acid in the bile fistula rat
}

\author{
N. D. GAllagheR ${ }^{1}$, J. P. W. WEBB ${ }^{2}$, AND A. M. DAWSON ${ }^{2}$ \\ From the Medical Unit, Royal Free Hospital, London
}

Normally, absorbed fatty acids are transported by the lymph after esterification. However, in rats with a bile fistula only a small fraction of the absorbed fatty acid is found in the lymph (Borgström, 1953; Saunders and Dawson, 1963) and an increased proportion is present as the free or unesterified fatty acid in the small bowel mucosa (Cesano and Dawson, 1966) and in the lymph (Saunders and Dawson, 1963; Gallagher, Webb, and Dawson, 1965). These results, together with experiments in vitro (Dawson and Isselbacher, 1960), have led to the proposal that impaired esterification of fatty acids in the intestinal mucosa of bile fistula rats results in the transport of unesterified fatty acid in the portal vein. The demonstration that in bile fistula rats sodium taurocholate reroutes the absorbed fat into the lymph and increases the proportion of esterified fatty acid in the lymph suggests that these disturbances are secondary to a deficiency of conjugated bile salts (Saunders and Dawson, 1963; Gallagher et al, 1965).

It is known that conjugated bile salts differ in their physiological properties for such unconjugated acids as desoxycholic acid: indeed, in vitro desoxycholate inhibits the esterification of long-chain fatty acids by the intestinal mucosa (Dawson and Isselbacher, 1960). Furthermore, in the blind loop syndrome significant amounts of unconjugated desoxycholate are found in the small bowel lumen (Donaldson, 1965; Kim, Spritz, Blum, Terz, and Sherlock, 1966; Tabaqchali and Booth, 1966) and it has been suggested that the mucosal effect of desoxycholate might account for the steatorrhoea which occurs in this condition (Dawson and Isselbacher, 1960; Donaldson, 1965). However, it may be dangerous to extrapolate from the in-vitro to the in-vivo situation (Dawson, Gallagher, Saunders, and Webb, 1964) and we have therefore

'Present address: University of Sydney, New South Wales, Australia 'Present address: St Bartholomew's Hospital, London studied the effect of desoxycholate on the absorption of oleic acid using bile fistula rats.

\section{MATERIALS AND METHODS}

Uniformly labelled (U-C ${ }^{14}$ )-oleic acid was obtained from the Radiochemical Centre, Amersham. Its purity, as determined by gas radiochromatography, was greater than $99 \%$. All the solvents and reagents which were used were of analytical grade.

An emulsion of $\left(\mathrm{U}^{-C^{14}}\right)$ oleic acid was prepared by dispersal with sodium desoxycholate by the method of Saunders and Dawson (1963), with the modification that the final solution was exposed to a Sonicator for 30 minutes.

Male albino rats of the Sprague-Dawley strain, weighing 200 to $250 \mathrm{~g}$, were permitted purina chow and water until the time of operation. The thoracic duct was cannulated under ether anaesthesia by a slight modification of the method of Bollman, Cain, and Grindlay (1948). Fine-bore polyethylene tubing was then inserted through a gastrostomy into the proximal duodenum. When necessary, the bile duct was cannulated immediately below the entrance of the left and right hepatic ducts. The rats were kept in restraining cages for the duration of the experiment. They were given free access to a solution containing $(\mathrm{g} / 100 \mathrm{ml})$ glucose, $5, \mathrm{NaCl}, 0.5$, and $\mathrm{KCl}, 0.04$.

Doses of $0.1 \mathrm{ml}$ of $\left(\mathrm{U}-\mathrm{C}^{14}\right)$ oleic acid, diluted with non-radioactive carrier, were administered on the day following the operation. When the solution of $\left(\mathrm{U}-\mathrm{C}^{14}\right)$ oleic acid containing sodium desoxycholate was administered, $1 \mathrm{ml}$ was injected initially and this injection was repeated after 30 minutes. The final concentration of the sodium desoxycholate in the solution was $10 \mathrm{mg} / \mathrm{ml}$.

The thoracic duct lymph was collected for three fourhour periods after the injection of the dose. The animals were then killed and the entire gastrointestinal tract was removed. Details of the extraction of the radioactivity in the lymph lipids and of the residual radioactivity in the gut and gut lumen have been given previously (Gallagher et al, 1965). The free fatty acids in the lymph were obtained by an alkaline methanol extraction. The radioactive samples were counted in $10 \mathrm{ml}$ of a liquid 
scintillation mixture containing $0.3 \% \quad 2: 5$ diphenyl oxazole and $0.01 \%$ p-bis-2-(5-phenyl oxazolyl)-benzene, in xylene. The efficiency of counting in a NuclearChicago liquid scintillation spectrometer was determined by the channel ratio method (Bruno and Christian, 1961). Moderate quenching was observed in the samples containing the residual radioactivity.

The amount of (U-C $\left.{ }^{14}\right)$ oleic acid which was absorbed was determined by subtracting the residual radioactivity from the radioactivity in the administered dose. The radioactivity in the lymph lipids was expressed as a percentage of the radioactivity which was absorbed and the free fatty acid content of the lymph was expressed as a percentage of the total radioactivity in the lymph. The results were analysed by Student's t test or an analysis of variance (Goulden, 1952).

\section{RESULTS}

THE ABSORPTION OF (U-C ${ }^{14}$ ) OLEIC ACID (TABLE I) When $0.1 \mathrm{ml}$ of $\left(\mathrm{U}-\mathrm{C}^{14}\right)$ oleic acid $(0.5 \mu \mathrm{c})$ was injected as the oil into the duodenum of a group of rats with an intact biliary system, a mean of $74.3 \%$ of the dose was absorbed, whereas a mean of $47.7 \%$ of the dose was absorbed in bile fistula rats $(\mathrm{P}<$ $0.001)$. The administration of the same amount of $\left(\mathrm{U}-\mathrm{C}^{14}\right)$ oleic acid in an emulsion of volume $2 \mathrm{ml}$, containing sodium desoxycholate $10 \mathrm{mg} / \mathrm{ml}$, resulted in the absorption of $35.7 \%$ of the dose. The absorption of the dose under these conditions was less than that in the bile fistula rats which were fed unemulsified oleic acid $(P<0.05)$.
THE TRANSPORT OF (U-C ${ }^{14}$ ) OLEIC ACID IN THE LYMPH (TABLE I) A mean of $46.4 \%$ of the absorbed oleic acid was recovered from the lymph of the rats with an intact biliary system but this was reduced to $21.1 \%$ in the bile fistula rats which were also fed unemulsified oleic acid ( $P<0.01)$. Administration of the oleic acid as a desoxycholate emulsion resulted in the recovery of $75.8 \%$ of the absorbed dose in the lymph of the bile fistula rats. The difference in the two groups of bile fistula rats was significant $(\mathbf{P}<0.001)$.

FREE FATTY ACID CONTENT OF LYMPH LIPIDS (TABLE II) Most of the oleic acid in the lymph in the rats with an intact biliary system was in the form of esterified fatty acid. A mean of $1 \cdot 7,4 \cdot 8$, and $5.9 \%$ of the total radioactivity was in the form of free fatty acid (in each collection period). Corresponding values of $21 \cdot 7,18.0$, and $38.0 \%$ were obtained in the bile fistula rats which were also fed unemulsified oleic acid. Administration of the oleic acid in the form of an emulsion with sodium desoxycholate resulted in a decrease in the proportion of free fatty acid in the lymph to $5.7 \%$ in the first collection period. This finding corresponded with the observation that, as in the control group of rats, over $75 \%$ of the fatty acid which was absorbed had appeared in the lymph by this time. The results in the first collection of each group of rats, when examined by an analysis of variance, were significant at the $1 \%$ level. No

TABLE I

INTESTINAL ABSORPTION AND TRANSPORT OF (U-C ${ }^{14}$ ) OLEIC ACID IN THE LYMPH OF BILE FISTULA RATS

\begin{tabular}{|c|c|c|c|c|c|c|}
\hline Preparation & Physical Form of Oleic Acid & $\begin{array}{l}\text { Number of } \\
\text { Experiments }\end{array}$ & & $\begin{array}{l}\text { Percentage of } \\
C^{14} \text { Dose } \\
\text { Absorbed }\end{array}$ & $\begin{array}{l}\text { Percentage of } \\
\text { Absorbed } C^{14} \text { in } \\
\text { Lymph Lipids }\end{array}$ & $\begin{array}{l}\text { Lymph Volume } \\
(\mathrm{ml})\end{array}$ \\
\hline Controls & Oil & 10 & $\begin{array}{l}\text { Mean } \\
\pm \text { SEM }\end{array}$ & $\begin{array}{r}74 \cdot 3 \\
\pm 3.5\end{array}$ & $\begin{array}{r}46.4 \\
+5.5\end{array}$ & $\begin{array}{r}48 \cdot 2 \\
\pm 4 \cdot 1\end{array}$ \\
\hline Bile fistula & Oil & 7 & $\begin{array}{l}\text { Mean } \\
\pm \text { SEM }\end{array}$ & $\begin{array}{r}47 \cdot 7 \\
\pm 3 \cdot 1\end{array}$ & $\begin{array}{r}21 \cdot 1 \\
\pm \quad 6 \cdot 0\end{array}$ & $\begin{array}{r}40.4 \\
\pm 4.5\end{array}$ \\
\hline Bile fistula & Desoxycholate emulsion & 6 & $\begin{array}{l}\text { Mean } \\
\pm \text { SEM }\end{array}$ & $\begin{array}{r}35 \cdot 7 \\
\pm 4 \cdot 7\end{array}$ & $\begin{array}{r}75.8 \\
\pm 10.0\end{array}$ & $\begin{array}{r}39.8 \\
\pm 8.4\end{array}$ \\
\hline
\end{tabular}

$0.1 \mathrm{ml}(0.5 \mu \mathrm{c})$ of oleic acid was present in a solution containing sodium desoxycholate, $10 \mathrm{mg} / \mathrm{ml}$.

TABLE II

LYMPH LIPID RADIOACTIVITY IN THE FORM OF FREE FATTY ACID AFTER FEEDING (U-C ${ }^{14}$ ) OLEIC ACID TO BILE FISTULA RATS ${ }^{1}$

\begin{tabular}{|c|c|c|c|c|c|c|}
\hline \multirow[t]{2}{*}{ Preparation } & \multirow[t]{2}{*}{ Physical Form of Oleic Acid } & \multirow{2}{*}{$\begin{array}{l}\text { Number of } \\
\text { Experiments }\end{array}$} & & \multicolumn{3}{|c|}{ Free Fatty Acid $(\%)$} \\
\hline & & & & Period 1 & Period 2 & Period 3 \\
\hline Controls & Oil & 6 & $\begin{array}{l}\text { Mean } \\
\pm \text { SEM }\end{array}$ & $\begin{array}{r}1.7 \\
\pm 0.3\end{array}$ & $\begin{array}{r}4.8 \\
\pm 0.8\end{array}$ & $\begin{array}{r}5.9 \\
\pm \quad 0.3\end{array}$ \\
\hline Bile fistula & Oil & 6 & $\begin{array}{l}\text { Mean } \\
\pm \text { SEM }\end{array}$ & $\begin{array}{r}21 \cdot 7 \\
\pm 5.9\end{array}$ & $\begin{array}{r}18.0 \\
\pm 6.8\end{array}$ & $\begin{array}{r}38.1 \\
+11.9\end{array}$ \\
\hline Bile fistula & Desoxycholate emulsion & 6 & $\begin{array}{l}\text { Mean } \\
\pm \text { SEM }\end{array}$ & $\begin{array}{r}5.7 \\
+2.9\end{array}$ & $\begin{array}{r}11.2 \\
\pm 3.9\end{array}$ & $\begin{array}{r}17.5 \\
+\quad 3.9\end{array}$ \\
\hline
\end{tabular}
period. 
differences were found in the free fatty acid content of the lymph in the later collections in the three groups.

\section{DISCUSSION}

The results of these experiments confirm the often repeated observation that the absorption of fatty acid is reduced in rats with a bile fistula. However, in contrast to the improvement in the absorption of fatty acid which occurs after the administration of a conjugated bile salt, such as sodium taurocholate (Saunders and Dawson, 1963; Gallagher et al, 1965), a slight depression was found when a comparable amount of the unconjugated bile salt, sodium desoxycholate, was used. It seems unlikely that this failure to stimulate fat absorption is due to an inhibition of the esterification of the absorbed fat by the small gut mucosa, such as has been demonstrated in vitro (Dawson and Isselbacher, 1960; Donaldson, 1965), for the desoxycholate efficiently rerouted the absorbed fat into the lymph and reduced the proportion of lymph free fatty acid towards normal; thus it would seem to be as efficient as taurocholate in stimulating the esterification of the absorbed fat in vivo. The fact that this reduction in the proportion of free fatty acid in the lymph was only observed in the first collection period (when most of the fat appeared) is probably due to the absorption of the desoxycholate in an animal whose enterohepatic circulation of bile had been interrupted. This has also been observed with taurocholate (Gallagher et al, 1965). These results make it unlikely that the presence of desoxycholate in the lumen of the small bowel of patients with the blind loop syndrome causes steatorrhoea by the inhibition of the mucosal esterification of absorbed long-chain fatty acids.

\section{SUMMARY}

It has been confirmed that in bile fistula fats an abnormally low proportion of $\mathrm{C}^{\mathbf{1 4}}$ oleic acid is transported by the lymph which contains an abnormally high proportion of labelled free fatty acid.

Oleic acid was further depressed by feeding it as an emulsion of desoxycholate. It seems unlikely that this was due to inhibition of esterification of the absorbed fat by the intestinal mucosa because the absorbed fat was rerouted into the lymph and the proportion of labelled free fatty acid returned towards normal. The implications of these findings in the pathogenesis of the blind loop syndrome are discussed.

One of us (N.D.G.) was in receipt of an overseas travelling fellowship from the Postgraduate Foundation, the University of Sydney. We wish to acknowledge the support of the Medical Research Council of Great Britain.

\section{REFERENCES}

Bollman, J. L., Cain, J. C., and Grindlay, J. H. (1948). Techniques for the collection of lymph from the liver, small intestine, or thoracic duct of the rat. J. Lab. clin. Med., 33, 1349-1352.

Borgström, B. (1953). On the mechanism of the intestinal fat absorption. $Y$. The effect of bile diversion on fat absorption in the rat. Acta physiol. scand., 28, 279-286.

Bruno, G. A., and Christian, J. E. (1961). Correction for quenching associated with liquid scintillation counting. Anal. Chem., 33, 650-651.

Cesano, L., and Dawson, A. M. (1966). Absorption of ${ }^{14} \mathrm{C}$ triolein in the bile fistula rat. Proc. Soc. exp. Biol. (N.Y.), 122, 96-99.

Dawson, A. M., and Isselbacher, K. J. (1960). Studies on lipid metabolism in the small intestine with observations on the role of bile salts. J. clin. Invest., 39, 730-740.

- Gallagher, N., Saunders, D. R., and Webb, J. (1964). Resynthesis and transport of long-chain fatty acids by the small gut. In Metabolism and Physiological Significance of Lipids. Edited by R. M. C. Dawson and D. N. Rhodes, pp. 243-255. Wiley, London.

Donaldson, R. M., Jr (1965). Studies on the pathogenesis of steatorrhea in the blina loop syndrome. J. clin. Invest., 44, 1815-1825.

Gallagher, N. D. Webb, J., and Dawson, A. M. (1965). The absorption of $\mathrm{C}^{14}$ oleic acid and ${ }^{14} \mathrm{C}$ triolein in bile fistula rats. Clin. Sci., 29, 73-82.

Goulden, C. H. (1952). Methods of Statistical Analysis, 2nd ed. Wiley, New York.

Kim, Y. S., Spritz, N., Blum, M., Terz, J., and Sherlock, P. (1966). The role of altered bile acid metabolism in the steatorrhea of experimental blind loop. J. clin. Invest., 45, 956-962.

Saunders, D. R., and Dawson, A. M. (1963). The absorption of oleic acid in the bile fistula rat. Gut, 4, 254-260.

Tabaqchali, S., and Bootk, C. C. (1966). Jejunal bacteriology and bile-salt metabolism in patients with intestinal malabsorption. Lancet, 2, 12-15. 